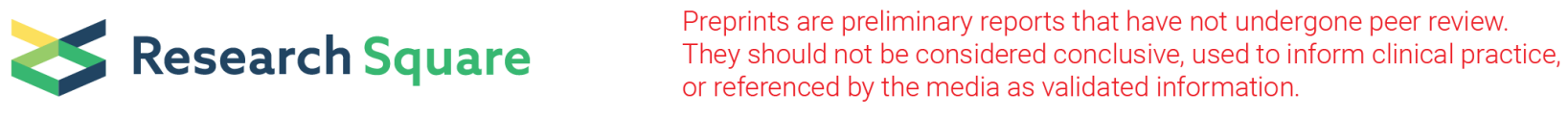

\title{
Dynamic Signature of tRNA-Derived small RNAs in Cancer Pathogenesis as a Promising Valuable Approach
}

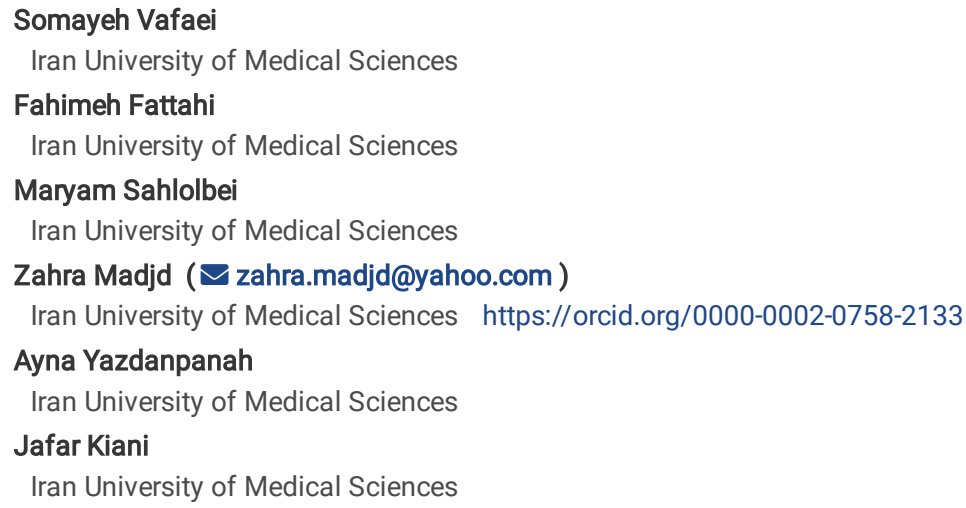

Research article

Keywords: Cancer, tRNA-derived small RNA fragments (tRFs), tRNA-derived small RNAs (tDRs), tRNA-derived small RNAs (tsRNA), tRNA halves (tiRNAs)

Posted Date: April 7th, 2020

DOI: https://doi.org/10.21203/rs.3.rs-21192/v1

License: @ (i) This work is licensed under a Creative Commons Attribution 4.0 International License. Read Full License

Version of Record: A version of this preprint was published at Critical Reviews in Eukaryotic Gene Expression on January 1st, 2020. See the published version at https://doi.org/10.1615/CritRevEukaryotGeneExpr.2020035372. 


\section{Abstract}

Background: Non-coding RNAs are a cluster of RNAs that do not encode functional proteins, and involve infrastructural and regulatory types, which transfer RNAs (tRNAs) belong to former and small RNAs (sRNA) to the latter one. Recently, tRNA-derived small RNAs (tDRs) were discovered among small non-coding RNA, as the newly discovered regulatory small RNA. It plays a role in pathological and physiological processes, which is frequently dysregulated in gene expression regulation. tsRNAs can be bounded to argonaute proteins and piwi proteins such as miRNAs and piRNAs sequentially. In addition, it can interact with DNA and histone methylation machinery

Results: In initial searching, 2744 unique articles were identified by bio electronically search of following databases: PubMed, Embase, Web of Science, Scopus, and google scholar up to 25 February 2020. Finally, after Full-text assessment 48 related article to gene expression profiling tsRNA in cancer were achieved.

Conclusions: In this systematic review, we summarized the most recent findings related to the expression of tsRNAs in 17 cancer types. We suggested that tsRNA in cancer field attracted the researchers' focus and effectively facilitated diagnostic and therapy approaches.

\section{Background}

Noncoding RNAs are a large group of endogenous and untranslated RNA molecules. Transfer RNAs (tRNAs) play a vital role as the second abundant RNA species in protein translation [1, 2]. Among small ncRNAs (sRNA) with the size $<200$ nucleotides (nt), different classes can be distinguished by their sizes, biogenesis, and functions. Not only microRNAs (miRNAs) and Piwi-interacting RNAs (piRNAs), but also recent tRNA-derived small RNAs (tsRNA) belong to this category $[3,4]$. Under different physiological conditions, the breakage of tRNAs happens that can lead to tRNA degradation products, which can be annotated in next generation sequencing (NGS) platform [5-7]. These tRNA fragments are totally classified into two groups based on the cleavage point of the tRNA transcript. TRNA-derived small RNA fragments (tRFs) are 18-22 nt and shorter than tRNA halves (tiRNAs) [8, 9]. TsRNAs share the length and mechanisms of action with miRNAs, instead of piRNAs; however, they could also interact with PIWI proteins [10].

There is little consensus over tRF production mechanism, and dicer-dependent cleavage of mature tRNAs has been suggested [11]. Dysregulation of tsRNAs could interfere in the gene expression in pre/post transcriptional and protein translation. Furthermore, researchers target the tsRNA via gene repression of mRNAs, reported construct silencing, translation inhibition, cell proliferation modulation, exonuclease mRNAs Xrn2-mediated degradation, Ybx1 protein displacement, and sense-induced trans-silencing [12]. Moreover, they have been engaged in cellular and pathophysiological tools, concerning porphyrin biosynthesis, reverse transcription, cell proliferation, differentiation, viability, cell signalling, control of viral replication, and utterly in disease ranging from metabolic disorders and neuro degenerative disease to various types of cancer [13-19].

At first, in 2009, small RNA sequencing data was recognized as tsRNA in prostate cancer [20]. Then, the scientists analyzed more samples, which were abundant in small RNA [21]. They declared that, this biomarker could be potentially applied in many cancer types as a screening and even be targeted for therapy. Moreover, tsRNA is essential in cell cycle proliferation and propagation as well as playing a significant role in tumorigenesis either oncogenic or tumor-suppressor functions [22]. Besides, induction and dysregulation of a set of hypoxia related tsRNAs and also tsRNA suppressive factors in Notch signaling pathway can help in maintenance and metastasis of cancer stem cell $[23,24]$. Unfortunately, the exact pathway of tsRNA in cancer has not been clarified yet and we design the schematic of tRNA-derived small RNAs biogenesis in Fig. 1. In this systematic review, we summarized the frequency and function of tsRNAs in different cancer types.

\section{Methods}

\section{Literature mining}

Case-control studies, which assessed circulating tsRNA markers, identified these markers in various types of cancer based on defined methods, which were included. We performed a bio electronically search of following databases: PubMed, Embase, Web of Science, Scopus, and google scholar up to 25 February 2020 for achieving total relevant articles published related to gene expression profiling tsRNA in cancer. Our search including syntax related to a topic that has been displayed in Table S1 with restriction on the English language.

S. Vafaei and F. Fattahi systematically searched and included eligible studies and removed duplicate publications and all remained articles reviewed. Discrepancies by consulting the other authors resolved. Next, the final full text publications read in detail. This review performed based on the Preferred Reporting Items related to Systematic Reviews and Meta-Analyses [25].

Study selection:

Observational studies (case-control) related to investigation tsRNA markers in cancer patient samples, cell lines and bioinformatics analysis were included with following inclusion factors: (I) articles were available and published in English. (II) tsRNA expression profiling in cell lines and patient which detected by molecular approach, (III) detection and validation of tsRNAs expression included sample types and numbers, (IV) classification of articles information including first author surname, year publication and study design.

\section{Study Exclusion}


The publications with the following characteristics were excluded from this study: (I) evidence on tsRNAs expression review, short report, letters, seminars, and books chapters, (II) non English articles, (III) any intervention that applied on experimental researches such as induction of drug resistance.

\section{Quality Assessment}

Newcastle Ottawa Scale (NOS) was applied for risk of bias assessment in observational studies [26]. This platform included score between 0 to 9 . NOS score was developed to assess the quality of nonrandomised studies that scores above six were classified as high quality article.

\section{Statistical analysis}

Meta-analysis was not conducted due to heterogeneity in the assessments of varied tsRNA expression.

\section{Microrna And Tsrna Association}

Advanced analysis of bioinformatics has introduced a huge number of rapid noncoding small RNAs. Some of miRNAs that were annotated on miRBase earlier, have been recently shown to be derived from tRNAs [27]. Thus, these cross mapping and mis-annotation lead to be incorrectly identified as miRNAs (miR-tRFs) based on mirBase literature review, which was finally removed from database, and are listed in detail in Table 1 [28, 29]. In fact, 20 tRNA-derived miRNAs were determined that have similar sequences with tRFs. Moreover, lysine degradation pathway was considered as a common regulatory pathway using DIANA-mirPath [30].

Table 1

Dead miRNA entry, miRNA-tRNA mis-annotations

\begin{tabular}{|c|c|c|c|c|c|}
\hline miRNA gene name & Amino acid -tRNA & miRBase & sequence (tRNA-derived) & chromosome & Type in MINTbase \\
\hline hsa-mir-321 & Arg-tRNA & MI0000543 & GCCAGGGATTGTGGGTTC & $16,7,17$ & i-tRF \\
\hline hsa-mir-594 & Arg-tRNA & MI0003606 & CCTAAGCCAGGGATTGTGGGTT & $16,7,17$ & i-tRF \\
\hline hsa-mir-565 & * & MI0003571 & GGCTGGCTCGCGATGTCTGTTT & 3 & - \\
\hline hsa-mir-720 & Thr- tRNA & MI0006654 & TCTCGCTGGGGCCTCCA & 5,14 & 3'-tRF \\
\hline hsa-mir-1280 & Leu- tRNA & MI0006437 & TCCCACCGCTGCCACC & $5,6,14,16,17$ & 3'-tRF \\
\hline hsa-mir-1308 & Gly- tRNA & MI0006441 & GCATGGGTGGTTCAGTGG & 1,21 & $5^{\prime}$-tRF \\
\hline hsa-mir-1974 & Glu- tRNA & MI0009984 & GTGGTTGTAGTCCGTGCGAGAAT & $\mathrm{Mt}^{*}, 5$ & i-tRF \\
\hline hsa-mir-1977 & Asn-tRNA & MI0009987 & TGATTAGGGTGCTTAGCTGTTA & $\mathrm{Mt}, 1$ & i-tRF \\
\hline hsa-mir-1978 & - & MI0009988 & AGGTTTGGTCCTAGCCTTTCT & Mt & - \\
\hline hsa-mir-1274a & Lys- tRNA & MI0006410 & GTCCCTGTTCAGGCGCCA & 6,11 & 3'-tRF \\
\hline hsa-mir-1274b & Lys- tRNA & MI0006427 & СCCTGTTCGGGCGCCA & $1,6,11,17$ & 3'-tRF \\
\hline hsa-mir-3172 & Ala- tRNA & MI0014203 & GTGGGGTTTTGCAGTCCTT & Mt, 1,14 & i-tRF \\
\hline hsa-mir-3676 & Thr- tRNA & MI0016077 & CCGTGTTTCCCCCACGCTT & 17 & - \\
\hline hsa-mir-4521** & Ser- tRNA & MIMAT0019058 & GCTAAGGAAGTCCTGUGCTCAG & 17 & - \\
\hline hsa-miR-4284** & Phe- tRNA & MIMAT0016915 & GGGCTCACATCACCCCAT & Mt & i-tRF \\
\hline
\end{tabular}

Since tRFs can be produced in a similar pathway to miRNA such as Argonaute/tRF interactions as well as dicer and drosha dependent [31]; hence, it is also notable that focusing on identifying miRNA processing details is crucial for understanding the biogenesis of tRF $[5,32]$.

\section{Results}

In initial searching, 2744 unique articles were identified, and finally, 258 of them were selected based on the title and abstract review evaluation. Full-text assessment yielded 48 relevant articles for final inclusion that has been drawn in Fig. 2. In this systematic review, according to discovery of tsRNAs importance in cancer field, we aimed at highlighting these biomarkers expressions and their potential role in cancers. Our analysis showed that, tsRNAs were investigated by researchers among 17 types of cancer. To clarify, here we classified the results based on the abundance of publications separately for each cancer.

\section{Breast Cancer}


Breast cancer leads $25 \%$ of women cancer cases to death in over 100 countries [33]. Aggressive Triple-negative breast cancer (TNBC) patients are suffering from shorter overall survival. The biogenesis and function of tRNA-derived microRNAs, as a gene regulator, should also be subjected to investigate [31]. Goodarzi et al., observed that, metastatic cells under the hypoxic conditions evade the up-regulation of these fragments and revealed a tumor suppressor function. The extracted data are summarized in Table 2 [23].

Bioinformatics studies demonstrated that, 5 ' tRNA halves-derived from some of the amino acid iso-acceptors are substantially deregulated [34]. tsRNAs have pivotal effects on the pathways regulated by KRAS, PIK3CA, and HRAS oncogenes [35]. 5'-tRFs, i-tRFs, and 3'-tRFs i-tRFs, as three abundant categories, suffer from many discrepancy among tissues, genders, and populations [36]. YB-1 play vital roles in mRNA localization, mRNA splicing, translation, cell differentiation, and extra/ intracellular signaling pathways. It binds to specific tsRNA and the induced RNAs (tiRNAs), which can regulate the miRNA biogenesis, miRNA processing machinery, and translational suppression [37].

By comparing the extra vesicles (EV) of miRNA profiles, it was indicated that, combination of tRNA-derived small RNA with miR signatures could determine tumor-derived EVs levels. To specify, miR-100, miR-125b, and let-7a are mirrored in the EVs, and correlations in tRNA-derived miRNA levels are only found in the EVs in comparison with cell line. [38]. Also, Honda et al. reported sex hormone-dependent tRNA-derived RNAs (SHOT-RNAs) as a transfer RNA (tRNA)-derived small RNA that was expressed in breast and prostate cancers and assisted in cell proliferation [39].

Sequencing results showed that, tRF-30-JZOYJE22RR33 and tRF-27-ZDXPH053KSN were upregulated in resistant patients compared to trastuzumab [6]. RNA sequencing population of CD44+ /CD24-/low breast cancer stem cell (BCSC) upregulated in TNBC. tDR-000620 and tDR-001262 expression levels were lower and upper in TNBC CSCs sequentially in contrast with non-TNBC CSCs [40].

In another study, miR-1280 (tRNA Leu-derived fragment) levels significantly increased in control < < early cancer < metastatic cancer prior to therapy. Besides, miR-1260, miR1280, and miR-720 up-regulated in ER-positive breast cancer [41]. Additionally, $5^{\prime}$-tiRNA-Val by inhibition of FZD3/Wnt/ $\beta$-Catenin signaling pathway served as diagnostic markers. TRNA-Val and tRNA-Asp were the most prevalent as well as lower levels of tRNA-Val-CAC (AS-tDR-001430) in tumor tissues and serum of the patients with higher TNM stages and lymph node metastasis and inhibition progression [42]. tsRNA-26576 upregulation induced migration while suppressing the cellular apoptosis, and served as a potential target therapy and also a predictive marker [43]. In another research, downregulation of tRF-32- Q99P9P9NH57SJ and tRF-17-79MP9PP were indicated as well as up regulation of tRF-32-XSXMSL73VL4YK [44]. Using high-throughput sequencing, circulating tDR-7816 was predicted as an oncogene effect on xenobiotic metabolic processes in early non-TNBC breast cancer. [45]. tRF3E derived from mature tRNA-Glu levels, as a tumor suppressor, significantly decreased in the blood of the patients with HER2 positive (control > early cancer > metastatic cancer) [46].

\section{Prostate Cancer}

Prostate cancer is ranked as the fifth cancer causing death among men [33]. SHOT-RNAs are abundantly expressed in androgen receptor (AR)-positive prostate lines as well as the patients' cancer tissues [39]. Lee et al. measured tRF-1001 (tRNA-SerTGA), which is expressed in cancer cell lines much more than tissues, and is also associated with cell proliferation [47].

Olvedy et al. suggested the ratio of tRFs derived from tRNA-LysCTT, and tRNAPheGAA (tRF-315/tRF-544 proportion) was emerged as a good indicator of disease progression [48]. Most tRNA-derived fragments that were identified in the prostate line were named as tRNAlle-AAT, tRNAlle-GAT, tRNALeu-TAA, tRNATrp-CCA, Mitochondrial_tRNA-Arg, Mitochondrial_tRNA-Asn, and Mitochondrial_tRNA-Phe [49]. Furthermore, Leucine (Leu), Histidine (His), Glycine (Gly), Glutamicacid (Glu), and Glutamine (GIn) contribute $44 \%$ of all the tRFs in the patients. They stated that, 3 '-tRFs from mitochondrially-derived tRNAs have differences by length, which were short in normal versus tumor [50].

\section{Lung Cancer}

Lung cancer is accompanied with high incidence and mortality, representing close to $18.4 \%$ cancer deaths [33]. Also, ts-3676 and ts-4521 are downregulated and linked with Piwi proteins. Besides, downregulation of ts-46 and ts-47 in lung cancer are documented [35, 51]. The upregulated expression level of tRF-LeuCAG in cell lines, serum, and tissues was detected. It was proved that, they cooperate in cell proliferation and cycle [52].

RNA-sequencing results indicated that, tRF- 5 and then tRF-3 are the most prevalent ones. Besides, eight tRFs that were enriched in cancer-related pathways such as Wnt signaling and carbon metabolism, were reported. They indicated that, knockdown of AStDR- 007333 and AS-tDR-010968 suppressed the cell apoptosis, proliferation, and migration [5].

\section{Ovarian Cancer}

This cancer is ranked as the fourth leading cancer death in women, and has the second rank in incidence and mortality next to breast cancer [33]. The scientists found that, ts-29 was overexpressed as compared with normal, and then verified that tRF5-Glu binds to a site in the $3^{\prime} U T R$ of BRAC3 to cancer proliferation. Moreover, upregulation of Ts-3 is proved in CLL as well as ovarian cancer $[35,53]$. High percentage of small total RNA was allocated to circulating tsncRNAs, which are enriched in Gly-tRNA and can predict abnormal cell proliferation with a high accuracy [54].

Zhang et al., reported that tRFs were involved in cell transcription, migration, and interaction with the MAPK and Wnt signaling pathways. Moreover, tRF-03357 was predictively targeted, due to promoting cell proliferation, migration, and invasion [55].

Page $4 / 19$ 


\section{Colorectal cancer (CRC)}

Colorectal cancer is considered as the second cancer leading to death [33]. Ballaty et al. showed that Ts-53 and ts-101 play roles in the first phases; whereas, Ts-36 is important at the final stages of cancer transformation. In addition, the oncogenic Ts-40 act in cancer development is undeniable [35].

TRF/miR-1280 (fragment derived from tRNA-Leu) supports the cancer stem-like cells (CSCs) function in cancer progression. Notably, CSC was suppressed via Notch signaling inactivation, and direct transcriptional repression of the Gata1/3 and miR-200b genes [56].

\section{Renal cancer (RCC)}

In clear cell renal cell carcinoma tissues of the patients, tRNA-Arg-CCT, tRNA-Glu-CTC, and -tRNA-Lys-TTT were circulated at lower levels, as a tumor suppressor [57]. tRFHis-GTG, as a novel tRNA-derived miRNA-like smRNA, which is probably induced by oxidative stress, is upregulated in metastatic form and promote migration [58]. In another study, researchers identified the expression of 32 tRNAs and down-regulation of 5'tRNA4-Val-AAC in tissues, which were correlated with staging and grading [59].

The expression levels of four tRNA halves (-Arg-CCT, -Leu-CAG, -Glu-CTC, and -Lys-TTT) indicated tumor suppressor as well as diagnostic and prognostic biomarkers [60]. They were not correlated with distant metastasis involvement and survival following nephrectomy [61, 62].

In Small non-coding RNAs deep sequencing (smRNA-seq) data sets, usually tRNAs, rRNAs, SnoRNA, and others appear to be fragmented. For intense, 5'-trf HisGTG knockdown by its LNA antisense inhibited the proliferation of tumor cells (ACHN, 769P, Caki-1, and Caki-2) and suppressed the migration and invasion [63]. Low expressions of both MiR-320d and URS00002901EC-tRNA were detected and then associated with better survival in rectal non metastatic cancer (M0) and with metastasis (M1) [64].

\section{Liver Cancer}

Fourth cancer leading to death is liver cancer that its screening is so painful [33]. Zhu et al. found unique tsRNAs (-ValTAC-3, -GlyTCC-5, -ValAAC-5, and GluCTC-5) that increased in plasma exosomal profiling, as a novel diagnostic biomarker [65].

\section{Pancreatic Cancer}

The worst tumors among the solid ones can be named as pancreatic cancer; almost only eight percentage of the patients under this condition have a 5-year survival. Bioinformatics predictions revealed AS-tDR-000064, AS-tDR-000102, AS-tDR-000069, AS-tDR-001391, and AS-tDR-000064 expressions in tissue samples [66].

\section{Gastric Cancer}

The second most cancer-related deaths worldwide is gastric cancer. Increased standards of hygiene in food and personal care and Helicobacter pylori eradication lead to steady decline in cancer incidence rates [67]. tiRNA-5034-GluTTC-2 was down regulated in tissues and plasmas, and was associated with tumor size and lower overall survival rate [68].

\section{Lymphoma cancer}

Maute et al., suggested that, CU1276 is tRNA-Gly-GCC independently expressed at three stages of mature B-cell differentiation, and one GC-derived is down regulated in lymphoma cell line [69].

\section{Chronic Lymphocytic Leukemia (cll):}

The most common human hematological malignancy was known to be chronic lymphocytic leukemia (CLL). i-tRF-GlyGCC could play the role of an indicator of unfavorable prognosis factors. Moreover, the patients without mutated IGHV locus overexpressing i-tRF-GlyGCC have shorter survival times [70].

Ballati et al. identified down-regulation of ts-46, ts-47, ts-53, ts-49, and ts-101, and also upregulation of ts-4 in CLL, and lung and Ts-3 in CLL and ovarian cancer, respectively [35]. Furthermore, they proved that, miR-3676 and miR-4521 are tsRNAs, and down-regulation of Ts-3676/4521 in CLL is correlated with Tcell leukemia/lymphoma 1 (TCL1) oncogene regulation and ZAP-70 methylation that co-deleted with p53. Thus, they identified ts-3676, ts-46, ts-4521, and ts47 as novel markers and targets for therapy and proposed that, loss of miR-3676 can cause high levels of TCL1 expression contributing to CLL progression $[35,51,71]$.

In another study, they verified that, ts-3676 and ts-4521 could be involved in gene promoter methylation, and ts-46 and ts-47 are downregulated in aggressive CLL as potential tumor-suppressors [10]. Papageorgiou et al. revealed that, i-tRF-GlyGCC and i-tRF-GlyCCC play significant roles as prognostic [72]. Mature tRFs (tRF-3 s, tRF-5 s, and internal tRFs) opposite to tsRNAs, suggested the oncogenic and/or tumor suppressor function [73]. 


\section{Myelodysplastic Syndromes And Acute Myeloid Leukemia}

Myelodysplastic syndromes (MDS) and acute myeloid leukemia (AML) are hematopoietic cell disorders, which frequently affect older adults [32]. The patients with AML had significantly more tDRs for Val and Gly compared with MDS supporting a biological phenomenon rather than the random cleavage events [74]. In another study, four tRNAs-derived small RNAs (tDRs) and 13 mitochondrial tDRs (mt-tDRs) were identified, which the response to treatment was predicted with DNMTIs [75].

\section{Head And Neck Squamous Cell Carcinoma}

Sixth most common human cancer is the Head and Neck Squamous Cell Carcinoma (HNSCC). Circulating levels of tRNA derived Ala, -Cys, and -Tyr significantly increased and tRNA-Arg, -Glu, -Gly, -Lys, -Trp, and -Val decreased [76]. Profiling small non-coding RNAs indicated that 5' tRNA-Val-CAC-2-1 half reduced in serum and tumor tissue of the patients (specifically, tRNA halves and YRNA fragments) [77].

\section{Testicular Germ Cell Tumors}

Downregulation of small RNA contigs, which were mainly tRNA-derived, were expressed in all samples. tRNAs derived Val, Gly, Glu, and Lys are overrepresented; meanwhile, a few tRNAs -Val-GTG/GTY and -Gly-GGY/GGG are higher in tRFs [78].

\section{Bladder Cancer}

tRNA-derived small RNAs indicated crosstalk in sncRNA pathways [5]. MiR-4454 and miR-21 overexpressions were found in FFPE-tumor tissue, plasma, urine exosome; while, miR-720/3007a (tRF), miR-205, miR-200c-3p, and miR-29b-3p were common in tumor/urine [79, 80].

\section{Chondrosarcoma}

The second most common bone primary cancer next to osteosarcoma is named chondrosarcoma. Green et al. found miR-140, as a significant part in embryonic bone development, which is highly expressed in advanced tumors as well as tRF-Gly-TCC as a tumor suppressor [81].

\section{Uveal Melanoma (uvm)}

The most primary intraocular malignancy considered ad uveal melanoma (UVM) with above-mentioned half of the patients with developing metastatic. Londin et al., findings indicated that, tRFs of nuclear origin are mostly 5'-tRFs, whereas mitochondrial tRFs are predominantly 3 '-tRFs. Additionally, nearly three quarters of the UVM tRFs are produced by ten tRNA isoacceptors that are listed by detail in the following Table [82]. 
Table 2

Distributions of tsRNA expression in seventeen types of cancer samples

\begin{tabular}{|c|c|c|c|c|c|c|c|}
\hline Type: & Status: & $\begin{array}{l}\text { Related } \\
\text { marker: }\end{array}$ & Method: & Cancer Type & $\begin{array}{l}\text { Sample Type: } \\
\text { ( patients/ } \\
\text { control ) }\end{array}$ & $\begin{array}{l}\text { Author/ year of } \\
\text { publication: }\end{array}$ & PMID: \\
\hline $\begin{array}{l}\text { tRFs derived from: } \\
\text { tRNA- Glu, -Asp } \\
\text { and -Gly, }\end{array}$ & Down & YBX1 & $\begin{array}{l}\text { qRT-PCR, } \\
\text { Genome-wide } \\
\text { profiling. }\end{array}$ & Breast & $\begin{array}{l}\text { 27/ } 4 \text { (tissue) } \\
\text {, Breast cancer } \\
\text { cell lines } \\
\text { (HEK293T, } \\
\text { MDA-MB-231, } \\
\text { CN34, CN-LM1a } \\
\text { and MDA-LM2). }\end{array}$ & $\begin{array}{l}\text { Goodarzi, } 2015 \\
\text { [23]. }\end{array}$ & 25957686 \\
\hline $\begin{array}{l}\text { 5' tRNA halves } \\
\text { derived from: } \\
\text { tRNA Arg, -Asn, - } \\
\text { Cys, -GIn, -Gly, -Leu, } \\
\text {-Ser, -Trp, and - Val }\end{array}$ & Up & - & $\begin{array}{l}\text { Small RNA } \\
\text { Sequencing }\end{array}$ & Breast & $5 / 5$ (serum) & $\begin{array}{l}\text { Dhahbi, } 2014 \\
\text { [34]. }\end{array}$ & 25520563 \\
\hline $\begin{array}{l}\text { 5' tRNA halves } \\
\text { derived from: } \\
\text { tRNA Asp and -Lys. }\end{array}$ & Down & & & & & & \\
\hline $\begin{array}{l}\text { ts- } 46, \\
\text { ts-47, } \\
\text { ts-49, } \\
\text { ts-53, } \\
\text { ts-86 } \\
\text { and ts-101 }\end{array}$ & Down & $\begin{array}{l}\text { PiwiL2, } \\
\text { KRAS, } \\
\text { p53 and } \\
\text { several } \\
\text { listed } \\
\text { tsRNA }\end{array}$ & $\begin{array}{l}\text { microarray, } \\
\text { qRT-PCR }\end{array}$ & $\begin{array}{l}\text { Colon, } \\
\text { Breast, } \\
\text { Ovarian and lung }\end{array}$ & $\begin{array}{l}15 \text { colon/ } 15 \\
\text {, } 9 \text { breast / } 9 \\
\text { '9 ovarian/ } 10 \\
\text { (tissue) } \\
\text { Cell lines: } \\
\text { lung (A-549, H- } \\
1299 \text { ), } \\
\text { Breast (MCF10- } \\
\text { AT1, KRAS-KI, }\end{array}$ & $\begin{array}{l}\text { Balatti, } \\
2017 \text { [35]. }\end{array}$ & 28696308 \\
\hline $\begin{array}{l}\text { ts-4, } \\
\text { ts-3, } \\
\text { ts-66 }\end{array}$ & Up & & & & $\begin{array}{l}\text { MCF-10A, } \\
\text { H1047R, } \\
\text { DKI2, DKI5, } \\
\text { MCF7, MDA- } \\
\text { MB-231and } \\
\text { MCF10A) and } \\
\text { prostate } \\
\text { (LNCaP and } \\
\text { RWPE-1) }\end{array}$ & & \\
\hline 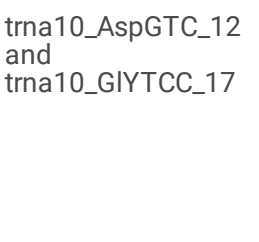 & $\begin{array}{l}\text { Abundance } \\
\text { between } \\
\text { the } \\
11 \text { tumor } \\
\text { and } \\
\text { adjacent } \\
\text { 11normal } \\
\text { tissue }\end{array}$ & - & $\begin{array}{l}\text { Bioinformatics } \\
\text { analysis, } \\
\text { qRT-PCR }\end{array}$ & Breast & $\begin{array}{l}311 / 452 \text { of } \\
\text { TCG Atlas, } \\
11 / 11, \\
8 \text { breast cancer } \\
\text { cell lines }\end{array}$ & $\begin{array}{l}\text { Telonis, } \\
2015 \text { [36]. }\end{array}$ & 26325506 \\
\hline $\begin{array}{l}\text { tRNA-derived: } \\
\text { miR-1308 and } \\
\text { miR-4284 }\end{array}$ & - & YB-1 & $\begin{array}{l}\text { microarray, } \\
\text { qRT-PCR } \\
\text { RNA Immuno } \\
\text { precipitation. }\end{array}$ & Breast & $\begin{array}{l}\text { cell lines (MCF7 } \\
\text { and MDA-MB- } \\
435 S \text { ) }\end{array}$ & $\begin{array}{l}\text { Blenkiron, } 2013 \\
\text { [37]. }\end{array}$ & 24260353 \\
\hline $\begin{array}{l}\text { tRNA-derived: } \\
\text { miR-720 and } \\
\text { miR-1274b }\end{array}$ & Up & $\begin{array}{l}\text { miR-100, } \\
\text { miR-125b, } \\
\text { let-7a }\end{array}$ & $\begin{array}{l}\text { NanoString } \\
\text { nCounter } \\
\text { miRNA Assay } \\
\text {, qRT-PCR }\end{array}$ & Breast & $\begin{array}{l}\text { MCF7 EVs } \\
\text { compare with } \\
\text { MCF7 }\end{array}$ & $\begin{array}{l}\text { Guzman, } 2015 \\
\text { [38]. }\end{array}$ & 25722304 \\
\hline $\begin{array}{l}\text { Sex Hormone- } \\
\text { dependent TRNA- } \\
\text { derived RNAs } \\
\text { (SHOT-RNAs) }\end{array}$ & Up & $\begin{array}{l}\text { sex } \\
\text { hormones } \\
\text { and their } \\
\text { receptors }\end{array}$ & $\begin{array}{l}\text { cP-RNA-seq, } \\
\text { qRT-PCR. }\end{array}$ & $\begin{array}{l}\text { Breast, } \\
\text { Prostate }\end{array}$ & $\begin{array}{l}\text { estrogen } \\
\text { receptor (ER)- } \\
\text { positive breast } \\
\text { cancer and } \\
\text { androgen } \\
\text { receptor (AR)- } \\
\text { positive } \\
\text { prostate cancer } \\
\text { cell lines }\end{array}$ & $\begin{array}{l}\text { Honda, } \\
2015 \text { [39]. }\end{array}$ & 26124144 \\
\hline
\end{tabular}




\begin{tabular}{|c|c|c|c|c|c|c|c|}
\hline Type: & Status: & $\begin{array}{l}\text { Related } \\
\text { marker: }\end{array}$ & Method: & Cancer Type & $\begin{array}{l}\text { Sample Type: } \\
\text { ( patients/ } \\
\text { control ) }\end{array}$ & $\begin{array}{l}\text { Author/ year of } \\
\text { publication: }\end{array}$ & PMID: \\
\hline $\begin{array}{l}\text { tRF-30- } \\
\text { JZOYJE22RR33 } \\
\text { and tRF-27- } \\
\text { ZDXPHO53KSN }\end{array}$ & Up & - & $\begin{array}{l}\text { Next } \\
\text { generation } \\
\text { Sequencing, } \\
\text { qRT-PCR }\end{array}$ & Breast & $\begin{array}{l}57 \text { women with } \\
\text { HER-2 positive, } \\
\text { breast cancer } \\
\text { cell lines } \\
\text { (SKBR3 and } \\
\text { JIMT-1) and } \\
\text { normal breast } \\
\text { epithelial cells } \\
\text { lines HBL-100 }\end{array}$ & $\begin{array}{l}\text { Sun, } \\
2018 \text { [6]. }\end{array}$ & 30153663 \\
\hline tDR- 001262 & Down & - & $\begin{array}{l}\text { Small RNA } \\
\text { Sequencing, } \\
\text { qRT-PCR }\end{array}$ & Breast & $\begin{array}{l}44 \text { primary } \\
\text { TNBC patients } \\
\text { and } 28 \text { primary } \\
\text { non- } \\
\text { TNBC(serum) } \\
\text { TNBC cell lines } \\
\text { (MDA-MB-231, } \\
\text { HCC-1937, and } \\
\text { MDA-MB-453), } \\
\text { non-TNBC cell } \\
\text { lines (MCF-7, } \\
\text { T47D and } \\
\text { SKBR3) and } \\
\text { Breast CSCs }\end{array}$ & $\begin{array}{l}\text { Feng, } \\
2018 \text { [83]. }\end{array}$ & 30239174 \\
\hline $\begin{array}{l}\text { tRNA-derived: } \\
\text { miR-1280 }\end{array}$ & Up & - & $\begin{array}{l}\text { MicroRNA } \\
\text { microarray } \\
\text { and qRT-PCR }\end{array}$ & Breast & $\begin{array}{l}232 / 40 \\
\text { (Blood) }\end{array}$ & $\begin{array}{l}\text { Park, } \\
2014 \text { [41]. }\end{array}$ & 25179838 \\
\hline tiRNAVal & Down & FZD3 & $\begin{array}{l}\text { small RNA } \\
\text { sequencing, } \\
\text { qRT-PCR }\end{array}$ & Breast & $\begin{array}{l}60 / \\
20 \text { ( serum), } \\
\text { Some tissue } \\
\text { samples } \\
\text { MDA-MB-231, } \\
\text { MCF-7 and } \\
\text { HBL-100 }\end{array}$ & Mo, 2019 [84]. & - \\
\hline tsRNA-26576 & Up & - & $\begin{array}{l}\text { Small RNA } \\
\text { sequencing } \\
\text { Real-time PCR }\end{array}$ & Breast & $\begin{array}{l}\mathrm{n}>4 / \mathrm{n}>4 \\
\text { (tissues), } \\
\text { Cell line: } \\
\text { MDA-MB-231 }\end{array}$ & Zhou, 2019 [43]. & 31118807 \\
\hline $\begin{array}{l}\text { tDR-7816, } \\
\text { tDR-5334 and } \\
\text { tDR-4733 }\end{array}$ & Down & $\begin{array}{l}\text { Some } \\
\text { proteins }\end{array}$ & $\begin{array}{l}\text { small RNA } \\
\text { sequencing, } \\
\text { qRT-PCR and } \\
\text { bioinformatics }\end{array}$ & Breast & 45/ 22(blood) & $\begin{array}{l}\text { Huang ,2019 } \\
{[45]}\end{array}$ & 31535382 \\
\hline tRF3E & Down & nucleolin & qRT-PCR & Breast & 47/23(plasma) & Falconi,2019[46] & 31560576 \\
\hline $\begin{array}{l}\text { tRF-32- } \\
\text { XSXMSL73VL4YK } \\
\text { tRF-32 } \\
\text { Q99P9P9NH57SJ } \\
\text { and tRF-17- } \\
\text { 79MP9PP }\end{array}$ & $\begin{array}{l}\text { Up } \\
\text { Down }\end{array}$ & - & $\begin{array}{l}\text { RNA } \\
\text { sequencing } \\
\text { Real-time PCR }\end{array}$ & Breast & )$^{16 / 16 \text { (tissues }}$ & $\begin{array}{l}\text { Wang, } 2019 \\
\text { [85]. }\end{array}$ & $10.2174 / 1389202920666$ \\
\hline tRF-1001 & Up & ELAC2 & $\begin{array}{l}\text { sequencing, } \\
\text { Northern } \\
\text { hybridization, } \\
\text { qRT-PCR and } \\
\text { splinted } \\
\text { ligation } \\
\text { assays }\end{array}$ & Prostate & $\begin{array}{l}\text { Cell lines } \\
\text { (LNCaP and C4- } \\
\text { 2) }\end{array}$ & $\begin{array}{l}\text { Lee, } \\
2009 \text { [20]. }\end{array}$ & 19933153 \\
\hline $\begin{array}{l}\text { tRF-544Phe, } \\
\text { tRF-368Arg, } \\
\text { tRF-562Gly and } \\
\text { tRF-542Glu }\end{array}$ & Down & - & $\begin{array}{l}\text { RNA- } \\
\text { sequencing, } \\
\text { qRT-PCR }\end{array}$ & Prostate & $\begin{array}{l}174 / 34 \\
\text { (tissue) }\end{array}$ & $\begin{array}{l}\text { Olvedy, } 2016 \\
\text { [48]. }\end{array}$ & 27015120 \\
\hline tRF-315lys & Up & & & & & & \\
\hline $\begin{array}{l}\text { TRF from: } \\
\text { Leu, Gly, His, Gln } \\
\text { and Glu }\end{array}$ & $\begin{array}{l}44 \% \text { all of } \\
\text { the trfs }\end{array}$ & $\begin{array}{l}\text { Some of } \\
\text { Messenger } \\
\text { RNAs } \\
\text { (mRNAs) }\end{array}$ & Bioinformatics & Prostate & $\begin{array}{l}472 \text { TCGA, } \\
5 / 5 \text { normal } \\
\text { (tissue), } \\
11 / 1 \text { (FFPE) }\end{array}$ & $\begin{array}{l}\text { Magee, } \\
2018 \text { [50]. }\end{array}$ & 29593348 \\
\hline $\begin{array}{l}\text { 5'-tRNA-Asp-GUC- } \\
\text { half, } \\
\text { 3'-tRNA-Asp-GUC- } \\
\text { half }\end{array}$ & $\begin{array}{l}\text { Up }{\text { ( } \text { cap }_{3}} \\
\text { compared } \\
\text { with bph } \\
\text { tissues) }\end{array}$ & - & qRT-PCR & Prostate & $\begin{array}{l}83 \text { patients (58 } \\
\text { CaP tissues } \\
\text { and } 25 \mathrm{BPH} 6) \\
\text { (FFPE } 5 \text { ), } 49 \\
\text { patients(serum) }\end{array}$ & $\begin{array}{l}\text { Zhao, } \\
2018 \text { [86]. }\end{array}$ & 30209018 \\
\hline
\end{tabular}




\begin{tabular}{|c|c|c|c|c|c|c|c|}
\hline Type: & Status: & $\begin{array}{l}\text { Related } \\
\text { marker: }\end{array}$ & Method: & Cancer Type & $\begin{array}{l}\text { Sample Type: } \\
\text { (patients/ } \\
\text { control ) }\end{array}$ & $\begin{array}{l}\text { Author/ year of } \\
\text { publication: }\end{array}$ & PMID: \\
\hline $\begin{array}{l}\text { 5'-tRNA-Glu-CUC- } \\
\text { half }\end{array}$ & $\begin{array}{l}\text { Up )serum } \\
\text { of } \\
\text { metastatic } \\
\text { patients( }\end{array}$ & & & & & & \\
\hline $\begin{array}{l}\text { ts-3676, } \\
\text { ts-4521 }\end{array}$ & Down & $\begin{array}{l}\text { Piwi } \\
\text { proteins }\end{array}$ & $\begin{array}{l}\text { microarray } \\
\text { chip, RT-PCR }\end{array}$ & $\begin{array}{l}\text { CLL, } \\
\text { Lung }\end{array}$ & $\begin{array}{l}23 \text { CLL/ } 8 \\
\text { (Blood), } \\
17 \text { lung / } 17 \\
\text { (tissue) and } \\
\text { H1299 and } \\
\text { A549 cells }\end{array}$ & $\begin{array}{l}\text { Pekarsky, } 2016 \\
\text { [7]. }\end{array}$ & 27071132 \\
\hline $\begin{array}{l}\text { AS-tDR- } 007333 \\
\text { and AS-tDR- } \\
010968\end{array}$ & Up & - & $\begin{array}{l}\text { RNA } \\
\text { sequencing, } \\
\text { qPCR }\end{array}$ & NSCLC & $\begin{array}{l}10 \text { pairs of pre- } \\
\text { and post- } \\
\text { operation } \\
\text { plasma } \\
\text { samples from } \\
\text { patients with } \\
\text { NSCLC }\end{array}$ & $\begin{array}{l}\text { Yang, } \\
2018 \text { [87]. }\end{array}$ & 10.1200/JCO.2018.36.15 \\
\hline tRF Leu-CAG & Up & - & $\begin{array}{l}\text { Next } \\
\text { generation } \\
\text { Sequencing, } \\
\text { qRT-PCR }\end{array}$ & Lung & $\begin{array}{l}\text { 133/ } 34 \\
\text { (serum), } \\
60 / 60 \text { (tissue) } \\
\text { and NSCLC } 6 \\
\text { cell lines } \\
\text { (SPCA-1, 95-D, } \\
\text { H1650, A549, } \\
\text { H1299, PC-9, } \\
\text { H23 cells) and } \\
16 \text { HBE control } \\
\text { cells. }\end{array}$ & $\begin{array}{l}\text { Shao, } \\
2017 \text { [88]. }\end{array}$ & 28378898 \\
\hline tRF5-Glu & Expressed & BCAR3 & $\begin{array}{l}\text { qRT-PCR, } \\
\text { Northern } \\
\text { analysis }\end{array}$ & Ovarian & $\begin{array}{l}\text { ovarian cancer } \\
\text { cell lines (PEO1, } \\
\text { PEO4, SKOV3, } \\
\text { 2008, } \\
\text { OVCAR3and } \\
\text { HEK293T cell } \\
\text { as positive } \\
\text { control). }\end{array}$ & $\begin{array}{l}\text { Zhou, } \\
2017[53] .\end{array}$ & 29221134 \\
\hline $\begin{array}{l}\text { tRF-03357 and tRF- } \\
03358\end{array}$ & Up & - & $\begin{array}{l}\text { Small RNA } \\
\text { sequencing } \\
\text {, qRT-PCR }\end{array}$ & Ovarian & $\begin{array}{l}23 / 18 \\
\text { (serum), } \\
\text { SK-OV-3 cells }\end{array}$ & $\begin{array}{l}\text { Zhang } \\
2019 \text { [89]. }\end{array}$ & 31496739 \\
\hline $\begin{array}{l}\text { tRF/miR-1280 } \\
\text { (tRNA Leu) }\end{array}$ & Down & $\begin{array}{l}\text { JAG2 } \\
\text { Gata1/3 } \\
\text { miR-200b } \\
\text { Zeb1 } \\
\text { Suz12 and }\end{array}$ & $\begin{array}{l}\text { qRT-PCR, } \\
\text { Western } \\
\text { blotting }\end{array}$ & Colorectal & $\begin{array}{l}\text { 30/tissue } \\
\text { Cell (HCT116, } \\
\text { HCT15, HT29, } \\
\text { Panc-1, and } \\
\text { 293T) }\end{array}$ & $\begin{array}{l}\text { Huang, } \\
2017 \text { [24]. }\end{array}$ & 28446464 \\
\hline \multirow[t]{2}{*}{$\begin{array}{l}\text { URS00002901EC- } \\
\text { tRNA }\end{array}$} & Up & miR-320d & $\begin{array}{l}\text { small RNA } \\
\text { sequencing }\end{array}$ & Rectal & 96 (serum) & $\begin{array}{l}\text { Mjelle, } \\
2017 \text { [64]. }\end{array}$ & 29163812 \\
\hline & & - & $\begin{array}{l}\text { small RNA } \\
\text { sequencing }\end{array}$ & Colon & $\begin{array}{l}\text { Some tissue } \\
\text { samples }\end{array}$ & $\begin{array}{l}\text { Xiong, } 2019 \\
\text { [90]. }\end{array}$ & 31173257 \\
\hline $\begin{array}{l}\text { 5'-tRNA halves: } \\
\text { 5'-tRNA Arg-CCT, } \\
\text { Glu-CTC, -Leu-CÁ, } \\
\text { and -Lys-TTT }\end{array}$ & Down & - & qRT-PCR & ccRCC & $\begin{array}{l}95 / 50 \text { renal } \\
\text { (tissues) and } \\
27 / 13 \text { (serum) }\end{array}$ & $\begin{array}{l}\text { Zhao, } \\
2018 \text { [57]. }\end{array}$ & 28765068 \\
\hline 5'tRNA4-Val-AAC & Down & - & $\begin{array}{l}\text { Small RNA } \\
\text { Sequencing, } \\
\text { qRT-PCR }\end{array}$ & ccRCC & $\begin{array}{l}118 / 74 \\
\text { (tissue) } \\
30 / 15 \text { (serum) }\end{array}$ & $\begin{array}{l}\text { Nientiedt, } 2016 \\
\text { [59]. }\end{array}$ & 27883021 \\
\hline 5'-tRFHis-GTG & Up & $\begin{array}{l}\text { Exportin-5 } \\
\text { and Ago } 2\end{array}$ & $\begin{array}{l}\text { Small RNA } \\
\text { sequencing }\end{array}$ & RCC & $\begin{array}{l}24 \text { (tissue)/ } \\
237 \text {, } \\
\text { RCC cell lines }\end{array}$ & $\begin{array}{l}\mathrm{Li}_{1} \\
2013 \text { [63]. }\end{array}$ & 10.1158/1538-7445.AMr \\
\hline $\begin{array}{l}\text { tsRNAs: } \\
\text { tRNA-ValTAC-3, - } \\
\text { GlyTCC-5, -ValAAC- } \\
5 \text { and -GluCTC-5 }\end{array}$ & Up & - & $\begin{array}{l}\text { small RNA } \\
\text { sequencing }\end{array}$ & Liver & $\begin{array}{l}\text { 5/ } 5 \text { normal } \\
\text { (plasma EVs) } \\
\text { and } \\
\text { EVs of SK-Hep1 } \\
\text { liver cancer } \\
\text { cells }\end{array}$ & $\begin{array}{l}\text { Zhu, } \\
2019 \text { [65]. }\end{array}$ & 30940133 \\
\hline $\begin{array}{l}\text { our tsRNAs (tRNA- } \\
\text { ValTAC-3, tRNA- } \\
\text { GlyTCC-5, tRNA- } \\
\text { ValAAC-5 and } \\
\text { tRNA-GluCTC-5 }\end{array}$ & $\begin{array}{l}\text { Up } \\
\text { regulated }\end{array}$ & - & & Liver & $\begin{array}{l}\text { Some plasma } \\
\text { exosome } \\
\text { samples } \\
\text { Cell line: } \\
\text { SK-Hep1 cells }\end{array}$ & Zhu, 2019 [65]. & 30940133 \\
\hline
\end{tabular}




\begin{tabular}{|c|c|c|c|c|c|c|c|}
\hline Type: & Status: & $\begin{array}{l}\text { Related } \\
\text { marker: }\end{array}$ & Method: & Cancer Type & $\begin{array}{l}\text { Sample Type: } \\
\text { (patients/ } \\
\text { control ) }\end{array}$ & $\begin{array}{l}\text { Author/ year of } \\
\text { publication: }\end{array}$ & PMID: \\
\hline $\begin{array}{l}\text { AS-tDR-000064, } \\
\text { AS-tDR-000069 } \\
\text { and AS-tDR- } \\
000102 \\
\text { AS-tDR-001391 }\end{array}$ & $\begin{array}{l}\text { Up } \\
\text { Down }\end{array}$ & - & $\begin{array}{l}\text { Small RNA } \\
\text { sequencing } \\
\text { Real-time PCR }\end{array}$ & Pancreatic & 3 / 3 (tissues ) & Jin, 2019 [91]. & 31452788 \\
\hline $\begin{array}{l}\text { tiRNA-5034- } \\
\text { GluTTC-2 }\end{array}$ & Down & - & qRT-PCR & Gastric & $\begin{array}{l}\text { Some tissue } \\
\text { and plasma } \\
\text { samples gastric } \\
\text { cancer cell } \\
\text { linesCell lines: } \\
\text { HGC-27, AGS, } \\
\text { BGC-823, SGC- } \\
1007901 \text {, and } \\
\text { MGC-803. } \\
\text { Cell line:GES-1 } \\
\text { (control) }\end{array}$ & Zhu, 2019 [92]. & 31104009 \\
\hline CU1276 & Down & RPA1 & $\begin{array}{l}\text { small RNA } \\
\text { sequencing } \\
\text {,qRT-PCR }\end{array}$ & B cell lymphoma & $\begin{array}{l}293 T \text { cells and } \\
\text { B-cell lines } \\
\text { normal GC B } \\
\text { cells }(n=4) \text { and } \\
\text { diffuse large B } \\
\text { cell lymphoma } \\
\text { (DLBCL) } \\
\text { primary } \\
\text { biopsies ( } n= \\
\text { 25) }\end{array}$ & $\begin{array}{l}\text { Maute, } 2013 \\
\text { [93]. }\end{array}$ & 23297232 \\
\hline i-tRF-Gly, GCC & Up & $\begin{array}{l}\text { unmutated } \\
\text { IGHV locus }\end{array}$ & qRT-PCR & CLL & 91/ 43 (blood) & $\begin{array}{l}\text { Karousi, } 2019 \\
\text { [70]. }\end{array}$ & 30945323 \\
\hline ts- 46 and ts -47 & Down & & Microarray & CLL & $23 / 8$ & $\begin{array}{l}\text { Balatti } \\
\text {, } 2015 \text { [71] } \\
\text {, } 2016 \text { [10]. }\end{array}$ & \\
\hline $\begin{array}{l}\text { ts-3676 } \\
\text { and ts-4521 }\end{array}$ & Down & TCL1 & Sequencing & & $539 / 146$ & & 25646413 \\
\hline i-tRF-GlyCCC & Down & - & qPCR & CLL & $91 / 43$ (blood) & $\begin{array}{l}\text { Papageorgiou, } \\
2019 \text { [94]. }\end{array}$ & 10.1002/hon.43_2631 \\
\hline $\begin{array}{l}\text { ts-36, } \\
\text { ts-42,and } \\
\text { ts-70 } \\
\text { (also profile of } \\
\text { significantly } \\
\text { deregulated } \\
\text { mature tRFs ) }\end{array}$ & Down & & $\begin{array}{l}\text { Next- } \\
\text { Generation } \\
\text { Sequencing, } \\
\text { qRT-PCR }\end{array}$ & CLL & 20/14(blood) & $\begin{array}{l}\text { Veneziano,2019 } \\
\text { [73] }\end{array}$ & $10.1073 /$ pnas. 191369511 \\
\hline $\begin{array}{l}\text { tRNA-derived small } \\
\text { RNAs: } \\
\text { tRNA-Val and -Gly }\end{array}$ & Up & - & $\begin{array}{l}\text { Small RNA } \\
\text { Sequencing }\end{array}$ & MDS with AML & $\begin{array}{l}19 \text { MDS with } \\
\text { no known } \\
\text { AML/ } 11 \text { MDS } \\
\text { that later } \\
\text { transformed to } \\
\text { AML/ } 10 \text { MDS } \\
\text { with AML } \\
\text { (FFPE) }\end{array}$ & $\begin{array}{l}\text { Guo, } \\
2017 \text { [74]. }\end{array}$ & 28084850 \\
\hline $\begin{array}{l}\text { tRNA-derived small } \\
\text { RNAs: } \\
\text { tRNA10.TC, } \\
\text { tRNA8.AlaTGC and } \\
\text { tRNA4.ProAG }\end{array}$ & Up & - & $\begin{array}{l}\text { small RNA } \\
\text { sequencing }\end{array}$ & MDS & $\begin{array}{l}47 / 22 \text { (Bone } \\
\text { marrow } \\
\text { aspirate) }\end{array}$ & $\begin{array}{l}\text { Guo, } \\
2015 \text { [75]. }\end{array}$ & 26400237 \\
\hline $\begin{array}{l}\text { tRNA-derived small } \\
\text { RNAs: } \\
\text { tRNA58-LeuCAA, } \\
\text { 8-SeC (e)TCA and } \\
\text { 4-ThrAGT }\end{array}$ & Down & - & & & & & \\
\hline $\begin{array}{l}\text { 5' tRNA halves } \\
\text { derived from: } \\
\text { tRNA Ala, -Cys, and } \\
\text {-Tyr }\end{array}$ & Up & - & $\begin{array}{l}\text { small RNA } \\
\text { sequencing }\end{array}$ & HNSCC & $7 / 7$ (serum) & $\begin{array}{l}\text { Martinez, } \\
2015 \text { [76]. }\end{array}$ & 26057471 \\
\hline tRNA-Val-CAC-2-1 & $\begin{array}{l}\text { down- } \\
\text { regulated } \\
\text { in serum } \\
\text { and up- } \\
\text { regulated } \\
\text { in tissue }\end{array}$ & & $\begin{array}{l}\text { small RNA- } \\
\text { Seq }\end{array}$ & HNSCC & $\begin{array}{l}5 \text { (blood and } \\
\text { tissue) }\end{array}$ & Dhahbi,2019[77] & 31616639 \\
\hline
\end{tabular}




\begin{tabular}{|c|c|c|c|c|c|c|c|}
\hline Type: & Status: & $\begin{array}{l}\text { Related } \\
\text { marker: }\end{array}$ & Method: & Cancer Type & $\begin{array}{l}\text { Sample Type: } \\
\text { ( patients/ } \\
\text { control ) }\end{array}$ & $\begin{array}{l}\text { Author/ year of } \\
\text { publication: }\end{array}$ & PMID: \\
\hline $\begin{array}{l}\text { tRNA-derived small } \\
\text { RNAs: } \\
\text { Glu-GAG, } \\
\text { Glu-GAG and } \\
\text { Asp-GAY }\end{array}$ & Down & - & $\begin{array}{l}\text { small RNA } \\
\text { sequencing }\end{array}$ & TGC & 25/ 12 (tissue) & $\begin{array}{l}\text { Rounge, } 2015 \\
\text { [78]. }\end{array}$ & 26265322 \\
\hline miR-720/3007a & Up & $\begin{array}{l}\text { miR-451a } \\
\text { (Moderate } \\
\text { negative } \\
\text { correlation) }\end{array}$ & $\begin{array}{l}\text { Nano string } \\
\text { miRNA } \\
\text { assays, } \\
\text { Droplet digital } \\
\text { PCR }\end{array}$ & Bladder & $\begin{array}{l}\text { 16/11 (tissue, } \\
\text { plasma, urine } \\
\text { EVs) }\end{array}$ & $\begin{array}{l}\text { Armstrong, } 2015 \\
\text { [79]. }\end{array}$ & 26576778 \\
\hline tRF-Gly-TCC & Down & YBX1 & $\begin{array}{l}\text { Next } \\
\text { generation } \\
\text { Sequencing }\end{array}$ & Chondrosarcoma & $13 / 6$ & $\begin{array}{l}\text { Green, } \\
2017 \text { [81]. }\end{array}$ & 10.1002/jbmr.3363 \\
\hline $\begin{array}{l}\text { MT ValTAC, } \\
\text { MT TyrGTA, } \\
\text { MT ProTGG, } \\
\text { Nuc HisGTG, } \\
\text { Nuc GluTTC, } \\
\text { Nuc ValCAC, } \\
\text { Nuc GlyGCC, } \\
\text { Nuc GluCTC, } \\
\text { Nuc AlaCGC, and } \\
\text { Nuc GlnCTG }\end{array}$ & Up & $\begin{array}{l}\text { EIF1AX } \\
\text { mutant }\end{array}$ & Bioinformatic & UVM & 80 & $\begin{array}{l}\text { Londin, } 2019 \\
\text { [95]. }\end{array}$ & 31283110 \\
\hline
\end{tabular}

Down, down regulated.

Up, up regulated.

CSC, cancer stem cell.

TNBC, Triple-negative breast cancer.

CaP, Prostate cancer.

$\mathrm{BPH}$, benign prostate hyperplasia.

FFPE, formalin-fixed paraffin-embedded.

NSCLC, Non-small-cell lung carcinoma.

EVs, Extracellular vesicles.

MDS, Myelodysplastic syndrome.

AML, Adult acute myeloid leukemia.

HNSCC, Head and neck squamous-cell carcinoma.

TGC, Testicular germ cell

ccRCC, Clear cell renal cell carcinoma

\section{Risk Of Bias (quality) Assessment}

The quality of all articles related to the evaluation of tsRNA expression was assessed using the Newcastle-Ottawa Scale (NOS), and then reported in Table S2. Out of the 48 related articles, $42 \%, 27 \%, 20 \%$, and $2 \%$ scored $6,7,8$, and 9 , respectively, and $9 \%$ could were scored $x \leq 5$.

\section{Discussion}

In recent years, tRNA derivatives including tRNA-derived stress-induced RNAs (tiRNAs), tRNA-derived fragments (tRFs), tRNA-derived small noncoding RNAs (tDRs), and tRNA-derived small RNAs (tsRNAs), as $0.2-4 \%$ of sRNAs were generated by cleavage of the pre/ mature tRNAs under various environmental stress [13]. The most modified RNAs in any cell type are also tRNAs and mutations in biogenesis statuary tRNA modification enzymes that are correlated with a disease [96]. These biomarkers are involved under the stress condition; therefore, they play pivotal roles in cancer via RNA silencing and microenvironment manipulating. tRFs formed by Dicer or Rnase Z at other positions can shape a complex with argonaute (Ago) protein [97]. Our results stated that the experimental and bioinformatics studies in this field must be focused on the elucidation of common regulatory pathways [98]. Extracellular small non-coding RNAs are known to regulate the expression of genes involved in cell metabolism, and are produced via all cells by including extracellular vesicles [99]. 
Accumulating data discussed that, tRNAs and tRNA derivatives are important in translation reprograming [100], inhibition of the elF4F function, and binding to YB-1 [23, 101]. In response to exposure namely stress under unfavourable conditions, this molecules can affect cell survival [102, 103]. It was also worthy to declare that, they were observed in the fluid of the stressful and cancerous people. Packaging and delivery of the circulating tsRNA derived occurred in the extracellular environment, and also the inside functions contributed to malignancy [76].

Proto-oncogenes and tumor suppressor genes affected the transcription of tRNA by RNA pol III. There are 625 human tRNA genes, which are able to produce small RNAs [104]. Moreover, tRNA overexpression affected the metastasis and invasion abilities, which are due to their high stability and codon-rich transcripts translation [105].

\section{Conclusion}

The lack of functional data and mechanistic for most of the tRFs need more scientific search, which must be performed related to tsRNA expression and their molecular mechanism to an expansion of evidence in the above-mentioned cancers. The other view that must be noted is that, in reaching a better understanding, the gap between common and standard nomenclatures must be covered by the researcher.

Additionally, this potential biomarker could be evaluated in another common cancer, that it was not reported yet. Accumulating of all data's together can effectively assist scientists to properly identify the signature of tsRNA.

To sum up, in this systematic review, we perused the expression of tsRNA in 17 cancers that are listed in details in Table 2, and it was indicated that, the advent of this biomarker in cancer attracted the researchers' focus and effectively facilitated diagnostic and therapy approaches.

\section{Abbreviations}

tRFs

tRNA-derived small RNA fragments

tDRs

tRNA-derived small RNAs

tsRNA

tRNA-derived small RNAs

tiRNAs

tRNA halves

FFPE

formalin-fixed paraffin-embedded

NSCLC

Non-small-cell lung carcinoma

EVs

Extracellular vesicles

MDS

Myelodysplastic syndrome

AML

Adult acute myeloid leukemia

TGC

Testicular germ cell

ccRCC

Clear cell renal cell carcinoma

Down

down regulated

Up

up regulated

CSC

cancer stem cell

TNBC

Triple-negative breast cancer

CaP

Prostate cancer

BPH

benign prostate hyperplasia

HNSCC

Head and neck squamous-cell carcinoma

\section{Declarations}


Ethics approval and consent to participate

Not applicable

Consent for publication

Not applicable

Availability of data and materials

Competing interests

There are no financial and personal relationships with other people or organizations.

Funding

None.

Authors' contributions

S.V and F.F conceived of the presented idea. S.V collected interpreted and analyzed data and wrote the drafting of the article. Z.M and M.S developed, revised and approved the theory. F.F and A.Y performed the critical revision and verified the whole concept. Z.M and J.K encouraged the other author to investigate and supervised the findings of this work. All authors discussed the results and contributed to the final manuscript.

Acknowledgements

None.

\section{References}

1.

Fu Y, Lee I, Lee YS, Bao X. Small Non-coding Transfer RNA-Derived RNA Fragments (tRFs): Their Biogenesis, Function and Implication in Human Diseases. Genomics Inform. 2015;13(4):94-101.

2.

Han Li C, Chen Y. Small and Long Non-Coding RNAs: Novel Targets in Perspective Cancer Therapy. Curr Genom. 2015;16(5):319-26.

3.

Balatti V, Pekarsky Y, Croce CM. Role of the tRNA-Derived Small RNAs in Cancer: New Potential Biomarkers and Target for Therapy. Adv Cancer Res.

2017;135:173-87.

4.

Kim VN, Han J, Siomi MC. Biogenesis of small RNAs in animals. Nat Rev Mol Cell Biol. 2009;10(2):126-39.

5.

Keam SP, Hutvagner G. tRNA-Derived Fragments (tRFs): Emerging New Roles for an Ancient RNA in the Regulation of Gene Expression. Life. 2015;5(4):1638-

51.

6.

Sun CX, Yang F, Zhang YH, Chu JH, Wang J, Wang YF, Zhang YQ, Li J, Li YF, Fan RH, et al. tRNA-Derived Fragments as Novel Predictive Biomarkers for Trastuzumab-Resistant Breast Cancer. Cell Physiol Biochem. 2018;49(2):419-31.

7.

Pekarsky Y, Balatti V, Palamarchuk A, Rizzotto L, Veneziano D, Nigita G, Rassenti LZ, Pass HI, Kipps TJ, Liu CG, et al. Dysregulation of a family of short noncoding RNAs, tsRNAs, in human cancer. Proc Natl Acad Sci U S A. 2016;113(18):5071-6.

8.

Gebetsberger J, Polacek N. Slicing tRNAs to boost functional ncRNA diversity. RNA Biol. 2013;10(12):1798-806.

9.

Honda S, Kawamura T, Loher P, Morichika K, Rigoutsos I, Kirino Y. The biogenesis pathway of tRNA-derived piRNAs in Bombyx germ cells. Nucleic Acids Res.

2017;45(15):9108-20.

10.

Balatti RL, Veneziano D, Nigita G, Liu CG, Rassenti LZ, Kipps TJ, Croce CM, Pekarsky Y. Role of Ts-RNAs in CLL. Blood 2016, 128(22).

11.

Storz G, Vogel J, Wassarman KM. Regulation by small RNAs in bacteria: expanding frontiers. Molecular cell. 2011;43(6):880-91.

12.

Yeung ML, Bennasser Y, Watashi K, Le SY, Houzet L, Jeang KT. Pyrosequencing of small non-coding RNAs in HIV-1 infected cells: evidence for the processing of a viral-cellular double-stranded RNA hybrid. Nucleic Acids Res. 2009;37(19):6575-86.

13.

Giege R. Toward a more complete view of tRNA biology. Nat Struct Mol Biol. 2008;15(10):1007-14.

14.

Shen L, Gan M, Tan Z, Jiang D, Jiang Y, Li M, Wang J, Li X, Zhang S, Zhu L: A Novel Class of tRNA-Derived Small Non-Coding RNAs Respond to Myocardial Hypertrophy and Contribute to Intergenerational Inheritance. Biomolecules 2018, 8(3).

15.

Sharma U, Conine CC, Shea JM, Boskovic A, Derr AG, Bing XY, Belleannee C, Kucukural A, Serra RW, Sun F, et al. Biogenesis and function of tRNA fragments during sperm maturation and fertilization in mammals. Science. 2016;351(6271):391-6.

Page 13/19 
16.

Kim HK, Fuchs G, Wang S, Wei W, Zhang Y, Park H, Roy-Chaudhuri B, Li P, Xu J, Chu K, et al. A transfer-RNA-derived small RNA regulates ribosome biogenesis. Nature. 2017;552(7683):57-62.

17.

Goodarzi H, Liu X, Nguyen HC, Zhang S, Fish L, Tavazoie SF. Endogenous tRNA-Derived Fragments Suppress Breast Cancer Progression via YBX1 Displacement. Cell. 2015;161(4):790-802.

18.

Pavon-Eternod M, Gomes S, Geslain R, Dai Q, Rosner MR, Pan T. tRNA over-expression in breast cancer and functional consequences. Nucleic Acids Res. 2009;37(21):7268-80.

19.

Anderson P, Ivanov P. tRNA fragments in human health and disease. FEBS Lett. 2014;588(23):4297-304.

20.

Lee YS, Shibata Y, Malhotra A, Dutta A. A novel class of small RNAs: tRNA-derived RNA fragments (tRFs). Genes Dev. 2009;23(22):2639-49.

21.

Ugras S, Brill E, Jacobsen A, Hafner M, Socci ND, Decarolis PL, Khanin R, O'Connor R, Mihailovic A, Taylor BS, et al. Small RNA sequencing and functional characterization reveals MicroRNA-143 tumor suppressor activity in liposarcoma. Cancer Res. 2011;71(17):5659-69.

22.

Julia Jehn DR. tRNA-Derived Small RNAs: The Good, the Bad and the Ugly. Med One 2019, 4:e190015.

23.

Goodarzi H, Liu X, Nguyen HCB, Zhang S, Fish L, Tavazoie SF. Endogenous tRNA-derived fragments suppress breast cancer progression via YBX1 displacement. Cell. 2015;161(4):790-802.

24.

Huang B, Yang H, Cheng X, Wang D, Fu S, Shen W, Zhang Q, Zhang L, Xue Z, Li Y, et al. tRF/miR-1280 Suppresses Stem Cell-like Cells and Metastasis in Colorectal Cancer. Cancer Res. 2017;77(12):3194-206.

25.

Liberati A, Altman DG, Tetzlaff J, Mulrow C, Gotzsche PC, loannidis JP, Clarke M, Devereaux PJ, Kleijnen J, Moher D. The PRISMA statement for reporting systematic reviews and meta-analyses of studies that evaluate health care interventions: explanation and elaboration. PLoS Med. 2009;6(7):e1000100.

26.

Stang A. Critical evaluation of the Newcastle-Ottawa scale for the assessment of the quality of nonrandomized studies in meta-analyses. Eur $\mathrm{J}$ Epidemiol. 2010;25(9):603-5.

27.

Langenberger D, Bartschat S, Hertel J, Hoffmann S, Tafer H, Stadler PF. MicroRNA or Not MicroRNA? In: Advances in Bioinformatics and Computational Biology. Berlin Heidelberg: Springer; 2011. pp. 1-9.

28.

Schopman NC, Heynen S, Haasnoot J, Berkhout B. A miRNA-tRNA mix-up: tRNA origin of proposed miRNA. RNA Biol. 2010;7(5):573-6. 29.

Guo L, Liang T, Gu W, Xu Y, Bai Y, Lu Z. Cross-mapping events in miRNAs reveal potential miRNA-mimics and evolutionary implications. PLoS One. 2011;6(5):e20517.

30 .

Venkatesh T, Suresh PS, Tsutsumi R. tRFs: miRNAs in disguise. Gene. 2016;579(2):133-8.

31.

Iorio MV, Croce CM. MicroRNA dysregulation in cancer: diagnostics, monitoring and therapeutics. A comprehensive review. EMBO molecular medicine. 2012;4(3):143-59.

32.

Cogle CR, Craig BM, Rollison DE, List AF. Incidence of the myelodysplastic syndromes using a novel claims-based algorithm: high number of uncaptured cases by cancer registries. Blood. 2011;117(26):7121-5.

33.

Bray F, Ferlay J, Soerjomataram I, Siegel RL, Torre LA, Jemal A. Global cancer statistics 2018: GLOBOCAN estimates of incidence and mortality worldwide for 36 cancers in 185 countries. Cancer J Clin. 2018;68(6):394-424.

34.

Dhahbi JM, Spindler SR, Atamna H, Boffelli D, Martin DI. Deep Sequencing of Serum Small RNAs Identifies Patterns of 5' tRNA Half and YRNA Fragment Expression Associated with Breast Cancer. Biomark Cancer. 2014;6:37-47.

35.

Balatti V, Nigita G, Veneziano D, Drusco A, Stein GS, Messier TL, Farina NH, Lian JB, Tomasello L, Liu CG, et al. tsRNA signatures in cancer. Proc Natl Acad Sci USA. 2017;114(30):8071-6.

36.

Telonis AG, Loher P, Honda S, Jing Y, Palazzo J, Kirino Y, Rigoutsos I. Dissecting tRNA-derived fragment complexities using personalized transcriptomes reveals novel fragment classes and unexpected dependencies. Oncotarget. 2015;6(28):24797-822.

37. 
Blenkiron C, Hurley DG, Fitzgerald S, Print CG, Lasham A. Links between the oncoprotein YB-1 and small non-coding RNAs in breast cancer. PLoS ONE 2013, $8(11)$.

38.

Guzman N, Agarwal K, Asthagiri D, Yu LB, Saji M, Ringel MD, Paulaitis ME. Breast Cancer-Specific miR Signature Unique to Extracellular Vesicles Includes "microRNA-like" tRNA Fragments. Mol Cancer Res. 2015;13(5):891-901.

39.

Honda S, Loher P, Shigematsu M, Palazzo JP, Suzuki R, Imoto I, Rigoutsos I, Kirino Y. Sex hormone-dependent tRNA halves enhance cell proliferation in breast and prostate cancers. Proc Natl Acad Sci USA. 2015;112(29):E3816-25.

40.

Feng W, Li Y, Chu J, Li J, Zhang Y, Ding X, Fu Z, Li W, Huang X, Yin Y. Identification of tRNA-derived small noncoding RNAs as potential biomarkers for prediction of recurrence in triple-negative breast cancer. Cancer Med 2018.

41.

Park IH, Kang JH, Lee KS, Nam S, Ro J, Kim JH. Identification and clinical implications of circulating microRNAs for estrogen receptor-positive breast cancer. Tumor Biology. 2014;35(12):12173-80.

42.

Mo DP, Jiang P, Yang YN, Mao XL, Tan XY, Tang X, Wei D, Li B, Wang XM, Tang L, et al. A tRNA fragment, 5 '-tiRNA(val), suppresses the Wnt/beta-catenin signaling pathway by targeting FZD3 in breast cancer. Cancer Lett. 2019;457:60-73.

43.

Zhou J, Wan F, Wang Y, Long J, Zhu X. Small RNA sequencing reveals a novel tsRNA-26576 mediating tumorigenesis of breast cancer. Cancer Management Research. 2019;11:3945-56.

44.

Wang X, Yang Y, Tan X, Mao X, Wei D, Yao Y, Jiang P, Mo D, Wang T, Yan F. Identification of tRNA-derived fragments expression profile in breast cancer tissues. Curr Genomics. 2019;20(3):199-213.

45.

Huang Y, Ge H, Zheng M, Cui Y, Fu Z, Wu X, Xia Y, Chen L, Wang Z, Wang S, et al. Serum tRNA-derived fragments (tRFs) as potential candidates for diagnosis of nontriple negative breast cancer. J Cell Physiol. 2020;235(3):2809-24.

46.

Falconi M, Giangrossi M, Zabaleta ME, Wang JB, Gambini V, Tilio M, Bencardino D, Occhipinti S, Belletti B, Laudadio E, et al. A novel 3 '-tRNA(Glu)-derived fragment acts as a tumor suppressor in breast cancer by targeting nucleolin. Faseb Journal. 2019;33(12):13228-40.

47.

Lee YS, Shibata Y, Malhotra A, Dutta A. A novel class of small RNAs: tRNA-derived RNA fragments (tRFs). Genes Development. 2009;23(22):2639-49.

48.

Olvedy M, Scaravilli M, Hoogstrate Y, Visakorpi T, Jenster G, Martens-Uzunova ES. A comprehensive repertoire of tRNA-derived fragments in prostate cancer. Oncotarget. 2016;7(17):24766-77.

49.

Martens-Uzunova ES, Jalava SE, Dits NF, Van Leenders GJLH, Møller S, Trapman J, Bangma CH, Litman T, Visakorpi T, Jenster G. Diagnostic and prognostic signatures from the small non-coding RNA transcriptome in prostate cancer. Oncogene. 2012;31(8):978-91.

50.

Magee RG, Telonis AG, Loher P, Londin E, Rigoutsos I. Profiles of miRNA Isoforms and tRNA Fragments in Prostate Cancer. Scientific Reports 2018 , 8.

51.

Pekarskya Y, Balatti V, Palamarchuk A, Rizzotto L, Veneziano D, Nigita G, Rassenti LZ, Pass HI, Kipps TJ, Liu CG, et al: Dysregulation of a family of short noncoding RNAs, tsRNAs, in human cancer. Proceedings of the National Academy of Sciences of the United States of America 2016, 113(18):5071-5076.

52 .

Shao Y, Sun Q, Liu X, Wang P, Wu R, Ma Z. tRF-Leu-CAG promotes cell proliferation and cell cycle in non-small cell lung cancer. Chem Biol Drug Des. 2017;90(5):730-8.

53.

Zhou K, Diebel KW, Holy J, Skildum A, Odean E, Hicks DA, Schotl B, Abrahante JE, Spillman MA, Bemis LT. A tRNA fragment, tRF5-Glu, regulates BCAR3 expression and proliferation in ovarian cancer cells. Oncotarget. 2017;8(56):95377-91.

54.

Peng EY, Shu Y, Wu Y, Zeng F, Tan S, Deng Y, Deng Y, Chen H, Zhu L, Xu H. Presence and diagnostic value of circulating tsncRNA for ovarian tumor. Mol Cancer. 2018;17(1):163.

55 .

Zhang MM, Li FF, Wang J, He WZ, Li Y, Li HY, Wei ZL, Cao YX. tRNA-derived fragment tRF-03357 promotes cell proliferation, migration and invasion in highgrade serous ovarian cancer. Oncotargets Therapy. 2019;12:6371-83.

56.

Huang B, Yang H, Cheng X, Wang D, Fu S, Shen W, Zhang Q, Zhang L, Xue Z, Li Y, et al. TRF/miR-1280 suppresses stem cell-like cells and metastasis in colorectal cancer. Can Res. 2017;77(12):3194-206.

57.

Zhao C, Tolkach Y, Schmidt D, Kristiansen G, Muller SC, Ellinger J. 5'-tRNA Halves are Dysregulated in Clear Cell Renal Cell Carcinoma. The Journal of urology. 2018;199(2):378-83. 
58.

Li Y, Wu X, Gao H, Jin J, Pal S, Li A, Guo C, Nelson R, Wang J, Kim Y, et al: 5'-tRFHis-GTG, a novel tRNA-derived novel miRNA-like small non-coding RNA, aberrantly expressed in metastatic renal cell carcinoma by promoting tumor cell proliferation, migration and invasion. Cancer Research 2013, 73(8).

59 .

Nientiedt M, Deng M, Schmidt D, Perner S, Müller SC, Ellinger J. Identification of aberrant tRNA-halves expression patterns in clear cell renal cell carcinoma.

Scientific Reports 2016, 6.

60 .

Zhao CM, Tolkach Y, Schmidt D, Kristiansen G, Muller SC, Ellinger J. 5 '-tRNA Halves are Dysregulated in Clear Cell Renal Cell Carcinoma. J Urol. 2018;199(2):378-83.

61.

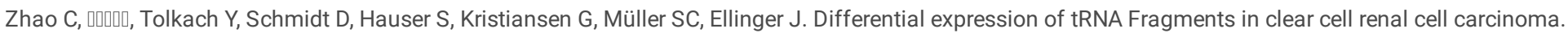
Urologe. 2017;56(1):32.

62.

Zhao C, Tolkach Y, Schmidt D, Kristiansen G, Müller SC, Ellinger J. 5'-tRNA-halves are dysregulated in clear cell renal cell carcinoma. Urologe. $2018 ; 57(1): 71$. 63.

Li Y, Gao H, Jin J, Pal S, Li A, Guo C, Nelson R, Wang J, Kim Y, Wang F, et al: 5'-tRFHis-GTG, a novel tRNA-derived novel miRNA-like small non-coding RNA, aberrantly expressed in metastatic renal cell carcinoma by promoting tumor cell proliferation, migration and invasion. Cancer Research 2013, 73(8).

64.

Mjelle R, Sellg K, Saetrom P, Thommesen L, Sjursen W, Hofsli E. Identification of metastasis-associated microRNAs in serum from rectal cancer patients. Oncotarget. 2017;8(52):90077-89.

65 .

Zhu L, Li J, Gong Y, Wu Q, Tan S, Sun D, Xu X, Zuo Y, Zhao Y, Wei YQ, et al: Exosomal tRNA-derived small RNA as a promising biomarker for cancer diagnosis. Molecular Cancer 2019, 18(1).

66.

Jin LEl, Zhu C, Qin X. Expression profile of tRNA-derived fragments in pancreatic cancer. Oncology Letters. 2019;18(3):3104-14.

67.

Sitarz R, Skierucha M, Mielko J, Offerhaus GJA, Maciejewski R, Polkowski WP. Gastric cancer: epidemiology, prevention, classification, and treatment. Cancer Manag Res. 2018;10:239-48.

68.

Zhu LW, Li TW, Shen YJ, Yu XC, Xiao BX, Guo JM. Using tRNA halves as novel biomarkers for the diagnosis of gastric cancer. Cancer Biomarkers. 2019;25(2):169-76.

69.

Maute RL, Schneider C, Sumazin P, Holmes A, Califano A, Basso K, Dalla-Favera R. TRNA-derived microRNA modulates proliferation and the DNA damage response and is down-regulated in B cell lymphoma. Proc Natl Acad Sci USA. 2013;110(4):1404-9.

70 .

Karousi P, Katsaraki K, Papageorgiou SG, Pappa V, Scorilas A, Kontos CK. Identification of a novel tRNA-derived RNA fragment exhibiting high prognostic potential in chronic lymphocytic leukemia. Hematological oncology 2019.

71.

Balatti V, Palamarchuk A, Rizzotto L, Veneziano D, Nigita G, Liu CG, Rassenti LZ, Kipps TJ, Croce CM, Pekarsky Y. Role of Ts-RNAs in CLL. Blood 2016, 128(22). 72.

Papageorgiou SG, Katsaraki K, Karousi P, Tsiakanikas P, Scorilas A, Pappa V, Kontos CK. The tRNA-derived rna fragments (TRFS) bearing the glycine anticodons GCC and ccc as emerging molecular biomarkers of unfavorable prognosis in chronic lymphocytic leukemia. Hematol Oncol. 2019;37:375-6. 73.

Veneziano D, Tomasello L, Balatti V, Palamarchuk A, Rassenti LZ, Kipps TJ, Pekarsky Y, Croce CM. Dysregulation of different classes of tRNA fragments in chronic lymphocytic leukemia. Proc Natl Acad Sci USA. 2019;116(48):24252-8.

74.

Guo Y, Strickland SA, Mohan S, Li S, Bosompem A, Vickers KC, Zhao S, Sheng Q, Kim AS. MicroRNAs and tRNA-derived fragments predict the transformation of myelodysplastic syndromes to acute myeloid leukemia. Leuk Lymphoma. 2017;58(9):1-15.

75.

Guo Y, Bosompem A, Mohan S, Erdogan B, Ye F, Vickers KC, Sheng Q, Zhao S, Li Cl, Su PF, et al. Transfer RNA detection by small RNA deep sequencing and disease association with myelodysplastic syndromes. BMC Genom. 2015;16:727.

76.

Martinez BV, Dhahbi JM, Lopez YON, Lamperska K, Golusinski P, Luczewski L, Kolenda T, Atamna H, Spindler SR, Golusinski W, et al. Circulating small non coding RNA signature in head and neck squamous cell carcinoma. Oncotarget. 2015;6(22):19246-63.

77.

Dhahbi J, Lopez YON, Schneider A, Victoria B, Saccon T, Bharat K, McClatchey T, Atamna H, Scierski W, Golusinski P, et al: Profiling of tRNA Halves and YRNA Fragments in Serum and Tissue From Oral Squamous Cell Carcinoma Patients Identify Key Role of 5 ' tRNA-Val-CAC-2-1 Half. Frontiers in Oncology 2019, 9. 78.

Rounge TB, Furu K, Skotheim RI, Haugen TB, Grotmol T, Enerly E. Profiling of the small RNA populations in human testicular germ cell tumors shows global loss of piRNAs. Molecular Cancer 2015, 14.

Page 16/19 
79.

Armstrong DA, Green BB, Seigne JD, Schned AR, Marsit CJ. MicroRNA molecular profiling from matched tumor and bio-fluids in bladder cancer. Molecular Cancer 2015, 14.

80 .

Qin C, Xu PP, Zhang X, Zhang C, Liu CB, Yang DG, Gao F, Yang ML, Du LJ, Li JJ. Pathological significance of tRNA-derived small RNAs in neurological disorders. Neural Regen Res. 2020;15(2):212-21.

81.

Green D, Fraser W. Transcriptional plasticity of tRNA fragments and microRNAs can be remodulated in chondrosarcoma. J Bone Miner Res. 2017;32:197. 82.

Londin E, Magee R, Shields CL, Lally SE, Sato T, Rigoutsos I. IsomiRs and tRNA-derived fragments are associated with metastasis and patient survival in uveal melanoma. Pigment Cell \& Melanoma Research.

83

Feng WT, Li YF, Chu JH, Li J, Zhang YH, Ding XR, Fu ZY, Li W, Huang X, Yin YM. Identification of tRNA-derived small noncoding RNAs as potential biomarkers for prediction of recurrence in triple-negative breast cancer. Cancer Med. 2018;7(10):5130-44.

84.

Mo D, Jiang P, Yang Y, Mao X, Tan X, Tang X, Wei D, Li B, Wang X, Tang L, et al. A tRNA fragment, 5'-tiRNA Val, suppresses the Wnt/ $\beta$-catenin signaling pathway by targeting FZD3 in breast cancer. Cancer Lett. 2019;457:60-73.

85 .

Wang X, Yang J, Guo G, Feng R, Chen K, Liao Y, Zhang L, Sun L, Huang S, Chen JL. Novel IncRNA-IUR suppresses Bcr-Abl-induced tumorigenesis through regulation of STAT5-CD71 pathway. Molecular Cancer 2019, 18(1).

86.

Zhao C, Tolkach Y, Schmidt D, Muders M, Kristiansen G, Muller SC, Ellinger J. tRNA-halves are prognostic biomarkers for patients with prostate cancer. Urologic Oncology-Seminars and Original Investigations 2018, 36(11).

87

Yang L, Yang W, Ding P, Wang Z, Zhai R. Genome-wide identification and characterization of aberrant tRNA-derived RNA fragments in non-small cell lung cancer. J Clin Oncol. 2018;36(15_suppl):e20539-9.

88.

Shao Y, Sun QL, Liu XM, Wang P, Wu RQ, Ma ZL. tRF-Leu-CAG promotes cell proliferation and cell cycle in non-small cell lung cancer. Chem Biol Drug Des. 2017;90(5):730-8.

89.

Zhang M, Li F, Wang J, He W, Li Y, Li H, Wei Z, Cao Y. tRNA-derived fragment tRF-03357 promotes cell proliferation, migration and invasion in high-grade serous ovarian cancer. Onco Targets Ther. 2019;12:6371-83.

90.

Xiong W, Wang X, Cai X, Xiong W, Liu Y, Li C, Liu Q, Qin J, Li Y. Identification of tRNAderived fragments in colon cancer by comprehensive small RNA sequencing. Oncol Rep. 2019;42(2):735-44.

91.

Jin L, Zhu C, Qin X. Expression profile of tRNA-derived fragments in pancreatic cancer. Oncol Lett. 2019;18(3):3104-14.

92

Zhu L, Li T, Shen Y, Yu X, Xiao B, Guo J. Using tRNA halves as novel biomarkers for the diagnosis of gastric cancer. Cancer Biomark A. 2019;25(2):169-76.

93.

Maute RL, Schneider C, Sumazin P, Holmes A, Califano A, Basso K, Dalla-Favera R. tRNA-derived microRNA modulates proliferation and the DNA damage response and is down-regulated in B cell lymphoma. Proc Natl Acad Sci U S A. 2013;110(4):1404-9.

94.

Sotirios Papageorgiou K, KarousiParaskevi, KarousiChristos KontosChristos, Kontos K. The tRNA-derived rna fragments (TRFS) bearing the glycine anticodons GCC and ccc as emerging molecular biomarkers of unfavorable prognosis in chronic lymphocytic leukemia. Hematol Oncol. 2019;37:375-6.

95

Londin E, Magee R, Shields CL, Lally SE, Sato T, Rigoutsos I: IsomiRs and tRNA-derived fragments are associated with metastasis and patient survival in uveal melanoma. Pigment cell \& melanoma research 2019

96.

Oberbauer V, Schaefer MR. tRNA-Derived Small RNAs: Biogenesis, Modification, Function and Potential Impact on Human Disease Development. Genes (Basel) 2018, 9(12).

97.

Huang SQ, Sun B, Xiong ZP, Shu Y, Zhou HH, Zhang W, Xiong J, Li Q. The dysregulation of tRNAs and tRNA derivatives in cancer. Journal of experimental clinical cancer research: CR. 2018;37(1):101.

98.

S.SureshbRieTsutsumic T: tRFs: miRNAs in disguise. gene 2016:133-138.

99

Wu Z, Wang L, Li J, Wang L, Wu Z, Sun X: Extracellular vesicle-mediated communication within host-parasite interactions. Frontiers in Immunology 2019, 10(JAN).

100.

Page $17 / 19$ 
Kim HK1, Fuchs G, Wang S,2, Wei W, Zhang Y1,2, Park H1,2, Roy-Chaudhuri B1,2, Li P5, Xu J1,2, Chu K1,2, Zhang F1,2, Chua MS4, So S4, Zhang QC5, Sarnow P3, Kay MA1,2:: A transfer-RNA-derived small RNA regulates ribosome biogenesis. Nature 2017 7;(552(7683):):57-62.

101.

Diebel KW, Zhou K, Clarke AB, Bemis LT. Beyond the Ribosome: Extra-translational Functions of tRNA Fragments. Biomarker insights. 2016;11(Suppl 1):1-8.

102.

Emara MM1IP, Hickman T, Dawra N, Tisdale S, Kedersha N, Hu GF, Anderson P. Angiogenin-induced tRNA-derived stress-induced RNAs promote stress-induced stress granule assembly. The Journal of biological chemistry 2010 2;(285(14):):10959-10968.

103.

Ivanov PEM, Villen J, Gygi SP, Anderson P. Angiogenin-induced tRNA fragments inhibit translation initiation. Molecular cell. 2011;43(4):613-23.

104.

Aristeidis G. Telonis PL. Yohei Kirino, and Isidore Rigoutsos: Nuclear and mitochondrial tRNA-lookalikes in the human genome. Front Genet. $2014 ; 5: 344$.

105.

Hani G, 3, ${ }^{*}$ Hoang CB Nguyen,1,3 Steven Zhang,1 Brian D. Dill,2 Henrik Molina,2 and Sohail F. Tavazoie1: Modulated Expression of Specific tRNAs Drives Gene Expression and Cancer Progression. Cell 2016, 2;(165(6)):1416-1427.

\section{Figures}

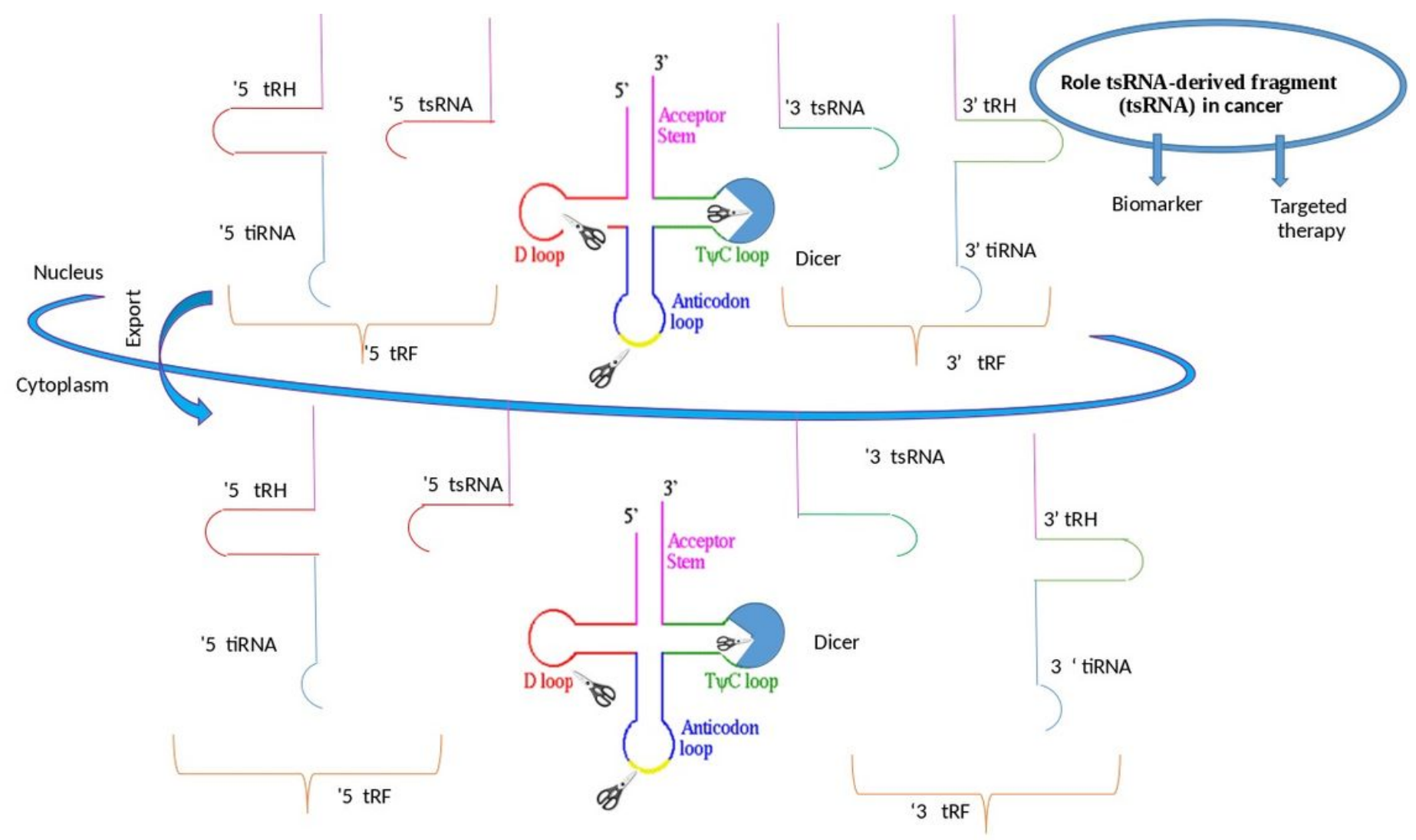

Figure 1

Biogenesis of tRNA-derived small RNAs 


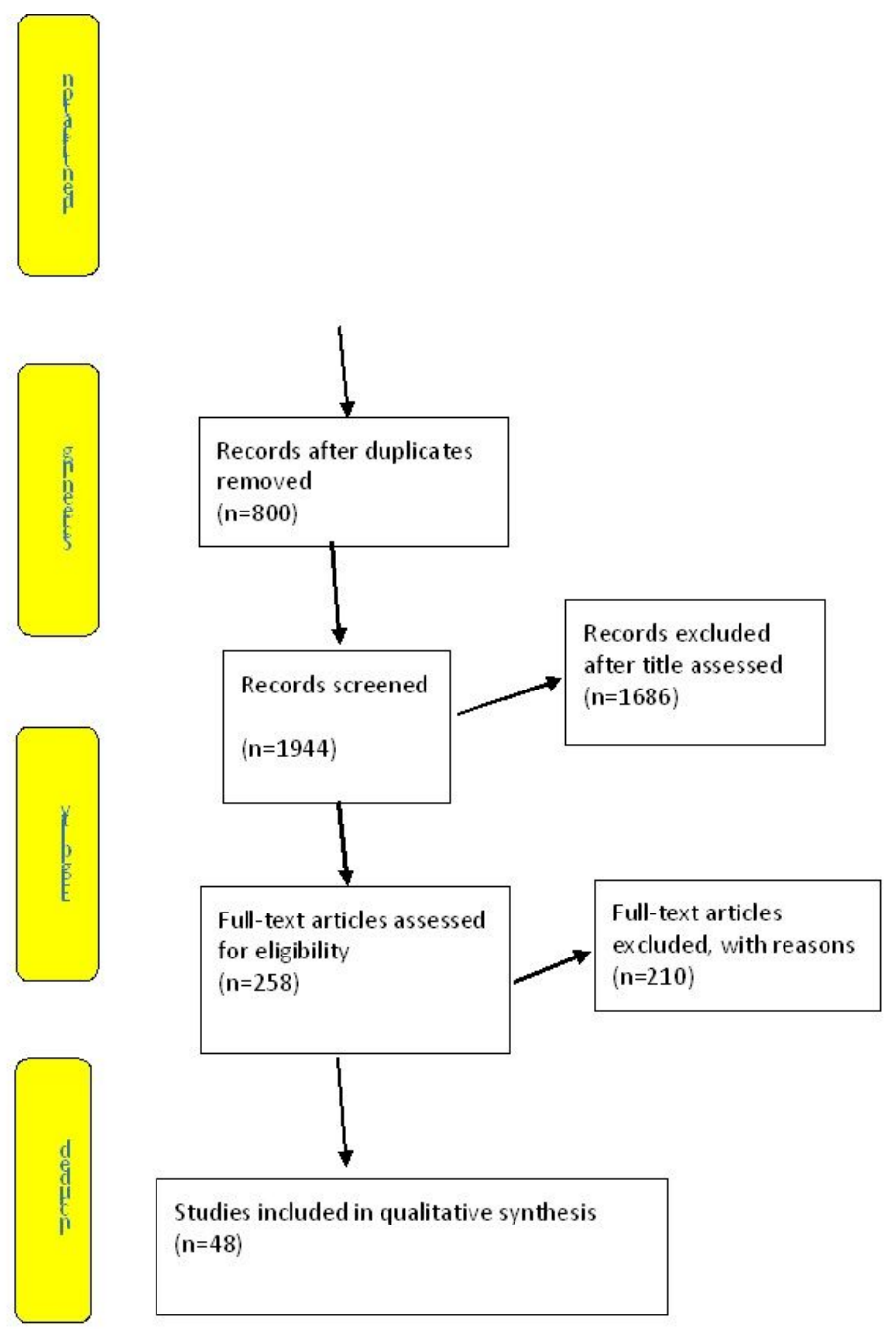

\section{Figure 2}

Design of PRISMA flow diagram explaining details of our search process was applied during the article selection.

\section{Supplementary Files}

This is a list of supplementary files associated with this preprint. Click to download.

- conflictofinterest.docx

- Requestforwaiver.docx

- Tables1.docx

- Tables2.docx

- CoverLetter.docx 